\title{
FEATURES OF THE EXCIPIENTS SELECTION FOR SEMI-SOLID DOSAGE FORMS
}

\author{
○T. A. Shostak, S. B. Bilous, N. I. Gudz', T. G. Kalynyuk \\ Danylo Halytsky Lviv National Medical University, Lviv
}

\begin{abstract}
Summary: The requirements for the selection of excipients during the pharmaceutical development of semi-solid medicinal preparations for cutaneous application were generalized from a point of view of their impact on the quality, efficacy and safety of medicinal preparations. It was justified which excipients from the examined groups should be used for the pharmaceutical development of ointments, gels, and creams. The information about physico-chemical and technological properties of excipients and their compatibility was summarized.
\end{abstract}

Key words: semi-solid dosage forms, excipients, pharmaceutical development.

Introduction. The composition of a dosage form (DF) in addition to the active pharmaceutical ingredients (APhls) includes excipients (Es), which is one of the pharmaceutical factors influencing the pharmaco-therapeutic effect of medicinal preparations (MPs). The nature and amount of an excipient (E) can change local bioavailability, storage conditions and shelf life.

An important factor of the medicinap preparation (MP) effectiveness is compatibility between active pharmaceutical ingredient (Aphl) and Es. Es possess appropriate physico-chemical properties and, depending on its nature, can enter into a more or less complex interaction with APhls and the environment. Therefore, during the pharmaceutical development (PD) of semi-solid dosage forms (SSDFs) particular attention should be paid to the Es choice considering certain type of DF [1].

The purpose of the study is to generalize national and foreign information materials connecting development of SSDFs compositions, review of controversial data on the characteristics, classification and selection of Es.

Methods. The objects of study are SSDFs for cutaneous application. Comparative method of Es study was used, as well as methods of information search, summarization and analysis of the literature data.

Results and discussion. The selection of a SSDF composition and technological methods is performed on the stage of PD, where grounds of quality, efficacy and safety of a MP are built in. The objects of research on PD are all components of a MP (Aphl and Es), and also DF, technological process and packaging materials, microbiological properties of the MP and compatibility of components $[1,2,3]$.

SSDFs for cutaneous application must meet certain requirements. They should be of homogeneous appearance. In the manufacture, packaging, storage and distribution of semi-solid preparations for cutaneous application, suitable

steps should be taken to ensure their microbiological quality according to the monograph of State Pharmacopoeia of Ukraine (SPU) «Microbiological quality of pharmaceutical preparations".

SSDFs intended for the use on very damaged skin must be sterile. They should be made in accordance with the monograph of SPU "Methods of preparation of sterile products." At first, the physical - chemical properties of APhl and selected Es have to be examined to develop a SSDF with optimal properties [1,4].

Es in combination with APhl (Aphls) form an effective and safe a MP. They are important components of SSDFs and their amount is approximately $90 \%$ or more. Therefore, during the PD of SSDFs it is very important to study the possibility of local irritant and sensitizing action of components [5]. SSDFs may contain antimicrobial preservatives, antioxidants, thickeners, emulsifiers, substances intended to adjust or stabilize the $\mathrm{pH}$, flavors and others Es permitted for medical usage $[1,4]$.

One of the easiest ways of prolongation of SSDFs action is increase its viscosity. Optimal viscosity does not slow down the absorption of active ingredients. The viscosity of the dispersion medium also provides the basic properties of the preparation in use: extrusion of tubes, application to the skin or mucosa, uniform of distribution, adhesive properties $[1,6]$.

The absorption of an APhl from a SSDF significantly is increased with the presence of «absorption activators» in their composition. Absorption activators (dimethyl sulfoxide, polyethylene oxide, surface-active agents (surfactants), ethanol, etc) increase the penetration of active substances through the skin by

ISSN 2312-0967. Фармацевтичний часопис. 2015. № 1 
dissolving the lipid components of the skin, increasing the thermodynamic activity of an APhl in the stratum corneum. However, in each case effect of absorbtion activators on release and absorption of an APh from SSDF for cutaneous application must be experimentally investigated the $[1,6]$. In compositions of many herbal medicines registered in Ukraine ethanol of various concentrations acts as an absorption activator, co-solvent, and preservative (Calendula ointment, Vundehil ointment, Kamident gel, Kamistad gel et al.). The same function is performed with propylene glycol, which is the constituent of ointments Pileks and Klotreks. It is also co-solvent and absorption activator $[1,7]$.

One of the most important indicators of specific action of preparations for local treatment of inflammatory processes is their osmotic activity. This is connected with need of dehydration influence of preparation on inflammation and surrounding tissue. Such a SSDF reduces swelling, helps to increase metabolism, and normalizes the patient's state $[1,6,8]$.

Defined rheological properties should be fulfilled during the production, storage and use, because they reflect both the medical and consumer properties of a SSDF [2]. In studying of the rheological properties the mutual influence of the components and external factors must be considered. Among external factors are temperature, duration and method of processing of dispersed systems, conditions and time of storage, transportation [5].

The Monograph of SPU 1.0 (2001) for SSDFs classified Es according to their functional performance. We reckon that it was reasonable and rational. However, in next additions of SPU 1.2 and 1.3 this classification has been withdrawn. Classification of Es according to the SPU 1.0, supplemented by us, are shown in Table 1 [9].
Фармацевтична технологія, біофармація, гомеопатія

Pharmaceutical technology, biopharmacy, homeopathy

Vehicles. When Vaseline is selected as a basis it is necessary to evaluate various sorts of Vaseline because the physical properties may depend on the origin and process of cleaning. Slight differences in the physical properties of Vaseline may have an essential impact on the release of the APhl from the DF. Vaseline is used as an independent basis for surface active dermatological ointments. Vaseline is combined with lanolin for application on mucous membranes and for the purpose of increasing resorptive capacity $[2,6,8,10,11]$.

Substances increasing the melting point and viscosity. Spermaceti is used as a thickener for very soft ointment bases. It has weak emulsifying properties and forms a coarse emulsion w/o.

Lanolin can be absorbed by skin and mucous membranes. It does not irritate them, is readily melted with fats, hydrocarbons and wax $[2,11]$.

Carnauba wax is widely used in food, cosmetic and pharmaceutical industry due to natural (vegetable) origin. Carnauba wax is very hard and fragile. It has a high melting point.

Plants waxes are used as emulsifiers and thickeners for modifying the crystal structure of other waxes if they are combined in mixtures. They are added to improve the consistency of creams and ointments, to stabilize the emulsion type w/o. It is necessary to be aware that they are incompatible with the oxidants $[11,15]$.

Macrogols are used as dispersants, softening and thickening agents. These properties depend on the molecular weight. They are characterized positive properties: low toxicity, no significant side effects, low sensitivity to changes in $\mathrm{pH}$, resistance to microbial contamination. Macrogols have a strong osmotic activity that causes their widespread use in the production of hydrophilic ointment for treatment of infected wounds, where they provide osmotic and dehydration action $[2,6,8,10,11]$.

Table 1. Classification of excipients used in the manufacture of semi-solid preparations

\begin{tabular}{|l|l|}
\hline \multicolumn{1}{|c|}{ Name of excipients } & \multicolumn{1}{c|}{ Main representatives } \\
\hline Semi-solid vehicles & Vaseline (Soft paraffin), lanolin (Wool fat) etc. \\
\hline $\begin{array}{l}\text { Substances increasing the } \\
\text { melting point and viscosity }\end{array}$ & $\begin{array}{l}\text { Paraffin, spermacet, macrogol of high molecular weight (1500), waxes, beeswax, } \\
\text { lanolin, white wax, yellow wax, carnauba wax, etc. }\end{array}$ \\
\hline Hydrophobic solvents & Mineral and vegetable oils, izopropilpalmitat, benzyl benzoate, etc. \\
\hline Water and hydrophilic solvents & $\begin{array}{l}\text { Ethanol and isopropanol, macrogol 200-600, propylene glycol, glycerol, dimethyl } \\
\text { sulfoxide, etc. }\end{array}$ \\
\hline Emulsifiers o /w & Sodium lauryl sulfate, emulsifying wax, emulsifier №1, etc. \\
\hline Gelling agents & Carbomer, cellulose derivatives, bentonite, gelatin, xanthan gum, starch, pectin, etc. \\
\hline Antimicrobial preservatives & $\begin{array}{l}\text { Benzalkonium chloride, myramistin, salts of chlorhexidine, benzyl alcohol, cresol, } \\
\text { ethanol, sorbic acid, macrogol, etc. }\end{array}$ \\
\hline Antioxidants & $\alpha$-tocopherol, ascorbic acid, citric acid, etc. \\
\hline Solubilizers & B-cyclodextrin, hydrophilic surfactant, etc. \\
\hline pH adjusters & $\begin{array}{l}\text { citric acid, sodium phosphate, ammonia, diethanolamine, triethanolamine, lactic } \\
\text { acid, sodium lactate, etc. }\end{array}$ \\
\hline
\end{tabular}

ISSN 2312-0967. Pharmaceutical review. 2015. № 1 
Фармацевтична технологія, біофармація, гомеопатія

Pharmaceutical technology, biopharmacy, homeopathy

Gelling agents. Gelling agents are used in compositions of SSDFs at a concentration from 0,5 to $10 \%$ [6]. Recently synthetic macromolecular polymers of acrylic acid are widely used, which are called carbomers, in pharmaceutical practice They show high thickening ability in a wide $\mathrm{pH}$ range. At concentrations from 1 to $2 \%$ carbopol easily swells and after mixing thickens polar environment (water, alcohol, etc.). The structural viscosity of gels depends on the concentration of Carbopol, $\mathrm{pH}$, nature of the base (sodium or ammonia hydroxide, triethanolamine) used for neutralization. The higher the concentration of Carbopol is, the higher structural viscosity is. Carbomers are widely used in the manufacture of gels, creams and ointments, in particular in preparations contacted with mucous membranes $[2,6,11]$.

Compositions based on bentonites should have a $\mathrm{pH}$ range 6.0 or above. Usually the concentration of bentonites used for thickening gels is in the range from 2 to $10 \%[2,6]$.

Gels of sodium carboxymethylcellulose (SodiumCMC) cannot be used if heavy or alkaline earth metals are used in a composition. When developing gels based on cellulose derivatives it is necessary to examine their compatibility with other components. A major disadvantage of cellulose derivatives is their lack of antimicrobial properties that requires usage of preservatives in gels. However, some cellulose derivatives (methyl cellulose and hydroxymetylcellulose) are not compatible with parabens. This limits selection of preservatives for such gels. Sodium-CMC can be also included in the composition of ointments and pastes as hydrogel base $[12,13]$.

Gels can be transparent or opaque, polar, wateralcohol or non-polar depending on the nature of gelling agents and solvents.

During PD gels it is recommended to use various gelling agents both within different groups of origin, and within the same group. If one of the requirements to the gel is transparency, hydroxymetylcellulose is preferable to methylcellulose $[6,8]$.

Emulsifiers $\mathrm{o} / \mathrm{w}$. Emulsifiers used in technology of MPs must meet the following requirements: 1) to be surface active to reduce surface tension; 2) to prevent coalescence by being absorbed quickly around dispersed droplets; 3 ) to facilitate mutual repulsion between particles by providing sufficient electrical capacity of drops; 4) to be able to increase

\section{References}

1. Nalezhni praktyky u farmacii: praktykum dlia studentiv vyshchykh med. i farm. navch. zakladiv $3-4$ rivniv akreditacii spec. «Farmacia» / N. I. Gudz', T. H. Kalynyuk, the viscosity to ensure consistency; 5) to be effective at low concentrations $[8,10]$.

Depending on the type of emulsion base $(0 / w$, w/o) there are used emulsifiers of two groups: 1) emulsifiers w/o, such as wool wax alcohols, esters of sorbitol, monoglycerides and fatty alcohols; 2) emulsifiers $\mathrm{o} / \mathrm{w}$, such as sulfated fatty alcohols, polysorbates, cetosterol ethers of macrogol or esters of fatty acids with macrogol [14].

Emulsifiers are classified into three categories based on their ability to ionization in water: anionic, cationic and nonionic emulsifiers.

Anionic emulsifiers. In general, these emulsifiers are acid-stable and allow to adjust the $\mathrm{pH}$ of the emulsion to the desired range 4,5-6,5, for example, sodium lauryl sulfate and soaps, such as triethanolamine stearate. Triethanolamine stearate is one of the most popular emulsifier for creams and lotions in usage today. They are produced in the process of reaction between stearinic acid in the hot oil phase and triethanolamine in hot water phase. Amount of triethanolamine determines $\mathrm{pH}$ of finished product.

Cationic emulsifiers. Cationic compounds have high surfactant effect, but are used less frequently as emulsifiers. They irritate the skin and eyes and have a considerable range of incompatibility, including anionic surfactants.

Nonionic emulsifiers. This class of emulsifiers regulates the $\mathrm{pH}$ of the emulsion as they are not ionized in solution. Nonionic emulsifiers may include both in the lipophilic and hydrophilic bases for obtaining hydrophilic-lipophilic balance $[2,6,8,10]$.

Emulsifiers are the main components of creams characterized by low viscosity. They reduce drying of skin, improve its softness and elasticity, maintain normal water balance of the skin, reduce inflammation $[2,6,8,11,16]$.

Excipients can simultaneously perform multiple functions, such as gelling agents, emulsifiers and substances that increase the melting point and viscosity of bases, also stabilizers of dispersed systems.

Conclusion. For the selection of Es for SSDFs for cutaneous application it is necessary to approach systematically: to study their perfomance, physicochemical properties and compatability with other Es; to conduct experimental studies on the selection of Es and their concentration. These results have to indicate that the selected Es as part of the SSDF is the best for the effectiveness of the SSDF application and recommended storage conditions.

S. B. Bilous, K. I. Smetanina. - Vinnicia: Nova Knyga, 2013. - 367s.

2. Nastanova 42-3.6:2004. Nastanova z jakosti. Likars'ki

ISSN 2312-0967. Фармацевтичний часопис. 2015. № 1 
Фармацевтична технологія, біофармація, гомеопатія

Pharmaceutical technology, biopharmacy, homeopathy

zasoby. Dopomizhni rechovyny. - Kyiv, 2004. - 12 s. 3. Nastanova 42-3.0:2011. Likars'ki zasoby. Farmacevtychna rozrobka (ICH Q8) / M. Liapunov, O. Bezugla, U. Pidpruzhnykov [ta in.] - Kyiv, MOZ Ukrainy, 2011. - 33 s. 4. Derzhavna Farmakopeia Ukrainy/Derzhavne pidpryemstvo «Naukovo-ekspertny farmakopeiny centr». - 1-e vyd. - Dopovnennia 2. - Kharkiv: Derzhavne pidpriemstvo «Naukovo-ekspertny farmakopeiny centr», 2008. - $620 \mathrm{~s}$.

5. Bilous S. B. Aktual'ni pytannia farmacevtychnoi rozrobky miakykh likarskikh zasobiv dlia zovnishnogo zastosuvannia/ S. B. Bilous, T. H. Kalynyuk, N. I. Gudz'// Farmacevtychny zhurnal. - 2010. - № 2. - S.16- 27.

6. Percev I. M. Farmacevticheskie i biologicheskie aspekty mazej / Pod. red. Prof. I. M. Perceva. - KH.,: Zolotye stranicy, 2003. - $288 \mathrm{~s}$.

7. Derzhavny reestr likars'kykh zasobiv Ukrainy. - www. drlz. kiev. ua.

8. Farmacevtychni ta medyko - biologichni aspekty likiv: navch. posib./ Percev I.M., Piminov O. Kh., Slobodianyuk M. M. [ ta in.] / za red. I. M. Perceva. - Vyd. 2, pererob. ta dopov. - Vinnicja: Nova Knyga, 2007. - 728 s.

9. Derzhavna Farmakopeia Ukrainy /Derzhavne pidpryemstvo «Naukovo-ekspertny farmakopeiny centr». - 1-e vyd. - Kh.:RIREG, 2001. - 531 s.

10. Tykhonov O.I. Aptechna tekhnologia likiv: pidr. dlia stud. farm. f-tiv VMNZ Ukrainy / O.I. Tykhonov, T.G. Jarnykh; za red. O. I. Tykhonova. - Vinnicia: Nova Knyga, 2007. - 640 s.
11. Dopomizhni rechoviny $v$ tekhnologiï likiv: vplyv na tekhnologichni spozhyvchi, ekonomichni kharakterystyki i terapevtychnu efektyvnist': navch. posib. dlia stud. vyshch. navch. farm. zakl. / avt. - uklad.: I. M. Percev, D. I. Dmytrievs'ky, V. D. Rybachuk [ ta in.]; za red. I. M. Perceva. - Kh.: Zoloti storinky, 2010.- 600 s.

12. Do pitannja viboru geleutvoryuvachiv pri rozrobci geliv / T. A. Shostak, N. I. Gudz', T. G. Kalynyuk, S. B. Bilous // Tekhnologichni ta biofarmacevtichni aspekty stvorennia likars'kykh preparativ riznoi napravlenosti dii: mater. 1 mizhn. nauk. - prak. internet konf. - Kharkiv, 2014. S. $188-189$.

13. Pitannia viboru dopomizhnykh rechovyn dlia geliv / T. A. Shostak, N. I. Gudz', T. G. Kalynyuk, S. B. Bilous // Suchasni dosiagnennia farmacevtychnoi tekhnologii i biotekhnologii : materialy 4 mizhn. nauk. - prakt. konf. Kharkiv, 2014. - S. $326-327$.

14. Derzhavna Farmakopeia Ukrainy / Derzhavne pidpryemstvo «Naukovo-ekspertny farmakopeiny centr». - 1-e vyd. - Dopovnennia 3. - Kharkiv: Derzhavne pidpryemstvo «Naukovo-ekspertny farmakopeiny centr», 2009. - $280 \mathrm{~s}$.

15. Pharmaceutical Preformulation and Formulation. A Practical Guide from Candidate Drug Selection to Commercial Dosage Form. Edited by Mark Gibson. - 2004. $-596 \mathrm{p}$.

16. Encyclopedia of Pharmaceutical Technology. - Third Edition. - edited by James Swarbrick - 2007.- Informa Healthcare USA, Inc.

\title{
ОСОБЛИВОСТІ ВИБОРУ ДОПОМІЖНИХ РЕЧОВИН ДЛЯ М'ЯКИХ ЛІКАРСЬКИХ ФОРМ
}

\author{
Т. А. Шостак, С. Б. Білоус, Н. І. Гудзь, Т. Г. Калинюк \\ Львівський національний медичний університет імені Данила Галицького
}

Резюме: узагальнено вимоги до підбору допоміжних речовин при фармацевтичній розробці м'яких лікарських засобів для зовнішнього застосування з позиції їх впливу на якість, ефективність та безпеку лікарського засобу. Обгрунтовано, які допоміжні речовини з опрацьованих груп доцільно використовувати для фармацевтичної розробки мазей, гелів та кремів, узагальнено інформацію про фізико-хімічні та технологічні властивості допоміжних речовин та їх сумісність.

Ключові слова: м'які лікарські форми, допоміжні речовини, фармацевтична розробка.

\section{ОСОБЕННОСТИ ВЫБОРА ВСПОМОГАТЕЛЬНЫХ ВЕЩЕСТВ ДЛЯ МЯГКИХ ЛЕКАРСТВЕННЫХ ФОРМ}

\author{
Т. А. Шостак, С. Б. Билоус, Н. И. Гудзь, Т. Г. Калынюк \\ Львовский национальный медицинский университет имени Данила Галицкого
}

\begin{abstract}
Резюме: обобщены требования к подбору вспомогательных веществ при фармацевтической разработке мягких лекарственных средств для наружного применения с позиции их влияния на качество, эффективность и безопасность лекарственного средства. Обоснованно, какие вспомогательные вещества с изученных групп целесообразно использовать для фармацевтической разработки мазей, гелей и кремов. Обобщена информация о физико-химических и технологических свойствах вспомогательных веществ и их совместимость.
\end{abstract}

Ключевые слова: мягкие лекарственные формы, вспомогательные вещества, фармацевтическая разработка. 